\title{
3.3. WORKAHOLISM AND ITS CONSEQUENCES FOR THE FUNCTIONING OF THE FAMILY SYSTEM
}

\begin{abstract}
Summary
Workaholism as a phenomenon examined in theories of addiction is primarily associated with harmful consequences for the functioning of an individual. Along with the development of the psychological mechanisms of addiction, there are more and more difficulties in professional and personal life of a workaholic. These changes affect not only the addict, but also his or her environment, especially the family. Work gradually occupies a space that should be allowed for the family, causing not only the physical absence of the addict, but also the emotional alienation. A strong need to control, which is clearly realized in the area of professional activity, is also evident in interpersonal relations. As a result, relationships with family and friends largely come down to the verification and accounting for carrying out tasks and responsibilities. At the same time, perfectionism characteristic of the functioning of a workaholic overstates the standards and level of expectations in relation to family members. For children it means a risk of living under the constant pressure of tough assessment of a parent, and striving for being the best is associated with the only way to experience the attention and conditional acceptance. The situation of spouses of people addicted to work appropriately characterizes specific adaptation to workaholic behaviour, which in literature is described as co-dependency. It includes among others: taking over extra responsibilities which are not performed by a busy spouse, a sense of guilt enhanced by grudges of the addict, low self-esteem, lack of emotional satisfaction, loneliness.

The article also presents the theoretical basis and practical indications concerning the role of the family system in the context of behavioural workaholic changes.
\end{abstract}

Keywords: work, workaholism, addiction, family system, family members

\section{Introduction}

Overworking issues are more and more popular in the contemporary world. As Golinska points out, it is caused by factors such as:

changes related to the progress of civilization which created favourable conditions for the development of new addictions, so called functional addictions, e.g. internet, gambling, eating, shopping addiction, as well as work addiction (Golińska, 2013);

the growing crisis within the family life that results in limiting the possibilities of meeting needs: security, intimacy, acceptance, and love - fundamental needs accomplished by the family system.

Work gives then the opportunity to experience something what was previously unattainable, i.e. approval, appreciation, pleasure and satisfaction (Golińska, 2008). 
Excessive engaging in professional activity does not necessarily mean the difficulty in psychological functioning. In the subject literature, we can distinguish at least several perspectives of understanding the problem of workaholism which are located at different points on a continuum from normal to abnormal. There are positions according to which workaholism results from „love for work” and, in this way, contributes to good health and happiness. Owing to work a person reaches a certain kind of mental health benefits, such as experience of significance and recognition and being responsible (Malinowska, 2014). On the other hand, workaholism as defined by dysfunction in psychological functioning is usually presented in terms of addiction. Then, this is the specific set of symptoms which is visible e.g. in the form of characteristic psychological mechanisms of emotional regulation (Golińska, 2008). The result is the emergence of harmful effects on mental and physical health which affect not only a workaholic but also their surroundings. In this article, workaholism perspective is assumed in the theory of addiction.

\section{Dysfunctional adaptation of workaholics' spouses}

Professional activity usually is an essential value involving the protection of the family living needs. However, in a situation when commitment to work becomes excessive, as a result it can lead to deprivation of basic needs carried out in a family, including emotional needs typical of marital dyad. Workaholic, because of their absence and/or unavailability, gradually withdraws from married life together, neglecting their duties and distancing themselves from arising problems. In the hierarchy of workaholic's values, marital relationship usually is in an inferior place to the career aspirations, which may result in the emergence of negative emotions and significant relationship disturbance (Golińska, 2008). Workaholics might experience difficulties since addicted spouses do not keep promises and consider work as an activity beyond any needs inherent in the role of a husband or wife. The situation of workaholics' partners becomes complicated both because of high social assessment of working hard and a system of illusion and denial which with time may develop in partners and activity of which may sustain mechanisms of addiction (Mieścicka, 2002). Based on analysis of the 100 wives of workaholics, Robison pointed out the following characteristics of their functioning:

- a feeling of being ignored, unnoticed, unloved;

- assuming excessive responsibility for marriage and family accompanied by a sense of loneliness;

- a feeling of being neglected by a husband whose commitment to working life definitely surpasses involvement in family life;

- a sense of control and manipulation by a husband;

- initiating various attempts to attract husband's attention, e.g. by showing interest in his work;

- a sense of tension, effort and lack of spontaneity in a relation with a husband;

- a sense of being less important in the face of a husband being in the central place

- experiencing a sense of guilt in the situation of expecting from a husband something else than issues connected with his professional activity; 
- a belief about low self-esteem originating from being compared to an admired by the environment husband;

- experiencing a clear discrepancy between the sphere of their own feelings such as grief, a sense of injustice, and position of environment indicating feelings of gratitude and pride in a husband (Robinson after Golińska, 2008).

Constantly repeating patterns of workaholic behaviours do not change despite the efforts of a spouse. With time, workaholics' partners who do not cope with increasing hostility and loneliness may experience clear physical and mental ailments (Kozak, 2009). At the same time, the most common are: allergies, hypertension, ulcers, neuroses, depression (Mieścicka, 2002). Similar to other addictions, the nature of interactions between the spouses and workaholics is often termed co-dependency. This concept includes a series of adjustment characteristics such as e.g. taking responsibility for the addicted, strong dependency of mental states on moods, behaviour and decisions of other people, suppression of emotions, feeling of helplessness and susceptibility to control from the outside (Killinger, 2007). Limited self-esteem, feeling of guilt and being misunderstood can also be present. It is worth stressing that not all studies confirm the negative impact of workaholism on the quality of a marital relationship (Malinowska, 2014). It is indicated by the need for caution in the interpretation of pointed relationships and their cause and effect connections. There is a possibility of the opposite direction of relation according to which excessive commitment to work is a way of compensation of unsatisfactory marital relationship (Golińska, 2008). This solution concerns especially the individuals with high level of emotional immaturity which show difficulties with interpersonal relations or fear for being emotionally involved. Professional activity offers a more available alternative to relationships with a close person. This is also supported by the fact that commitment to work has its objective justification and is realized with common social acceptance (Strzelczyk-Muszyńska, 2008). A mechanism of the vicious circle (typical of addictions) might also occur, with the problems with relationships causing escaping into workaholism, which consequently leads to a more tense atmosphere at home (Moczydłowska, 2005). The problem, therefore, requires further in-depth empirical testing.

\section{Possible difficulties experienced by children of workaholic}

Addiction of a family member affects the whole family system, causing essential changes in the dynamics of the processes occurring in this system. Serious consequences are likely to be observed in children who are susceptible to a strong influence and follow specific behaviours of their parents. Such problems have been well researched in families with alcohol problems. Children of alcoholics gradually acquire specific adjustment characteristics which are the source of serious emotional difficulties in an adult life. These acquired disorders are commonly known as an Adult Children of Alcoholics syndrome (ACoA). It seems that differences in socio-economic conditions between families with alcohol problem and families of workaholics are substantial and the discrepancies concerning consequences of these dependencies are also significant. Workaholism, often ,invisible" to the community, offers social 
gratification, especially due to the measurable material benefits. On the contrary, alcoholism might cause serious financial difficulties and a kind of social ostracism. However, since basic mechanisms of dependency are similar, dangerous emotional consequences might be experienced, even in early childhood (Golińska, 2006).

The imbalance concerning raising children at workaholics' family may eventually lead to dysfunctional parenthood and considerable difficulties in the functioning of children. Workaholics most often grow up themselves in a family of abnormal patterns of interpersonal relationships which then they copy in relations with family and friends. Most often, they experienced appreciation and love in their families only in a situation when they worked hard for it. With high probability, they will repeat similar patterns of conditional acceptance towards their children. A child of a workaholic will therefore take serious efforts of ,being the best”, so as to get at least a small token of appreciation and approval from a parent. However, when a child does not live up to unreasonable expectations, when they are not the best pupils, when they do not achieve successes and do not get prizes, they cannot count on signs of interest and enthusiasm, and they rather meet reprimand and cautions (Killinger, 2007). Contacts with a parent can be therefore constantly accompanied by anxiety and a sense of being controlled and evaluated. At the same time, a typical of workaholism perfectionism makes accomplishment by a child excessive standards that would satisfy a parent an extremely difficult task. It can intensify the ever-present sense of being imperfect hidden beneath the image of a perfect reliable, successful child. Robinson's research (Robinson after Guerreschi, 2005) shows that children of workaholic have a clear tendency to the self-critical attitudes and experiencing guilt. They know achievements of a perfect workaholic parent and internalize their patterns of functioning striving for achieving comparable standards. Workaholics model their activities which are frequently performed in stress, and this stimulation, if constantly repeated, might intensify the need for vocational stress in other family members (Golińska, 2006). A significant threat to children of workaholics is therefore development of similar patterns of involvement in professional activity and, eventually, mechanisms of addiction to work. Furthermore, factors that elevate the risk of dysfunctional behaviours concerning the work in adulthood also include:

- lack of appropriate bond between a parent and a child,

- hiding emotionalism by parents,

- other difficult experiences in the early years of a child's life (Wojdyło, 2010).

Typical of this group of children is also a sense of over-responsibility with parents described as ,parenthood” syndrome. It means taking over the duties of parents (e.g. the supervision of younger siblings) and excessive care and concern for their emotional comfort. At the same, the care the children take is inadequate to their age and capabilities, and takes place at the expense of their development needs. As a result, these children may become overly susceptible to environmental influences, satisfying their need for approval by fulfilling the expectations of others (Golińska, 2008). It is therefore understandable, as confirmed by the study of adult children of workaholics, greater likelihood of high level of anxiety, depression and difficulties in partnership (Guerreschi after Robinson, 2005). 


\section{Effect of changes in workaholic behaviours on the family system}

Behaviour of a workaholic might substantially affect the dynamics of mutual relationships in families. According to the systematic theory of family therapy, a family represents a multilevel structure of multilateral transactions and communication which occur according to the specific principles. From this standpoint, changes in behaviour of one of the family members affect behaviour of other people and function of the whole family system. In order to understand the mechanisms used by an individual, it is necessary to understand the principles that govern interactions in a specific family (Sęk, 2007). In the context of disturbances, this means that if one person experiences difficulties, the whole family is ,infected" and should be also diagnosed and should receive therapy. Therefore, a systematic therapy is oriented at implementation of broadly understood changes which lead to solving the problems experienced especially by a specific family member. Consequently, the therapeutic effects are oriented at the family structure, communication patterns and principles that affect the whole family system (Czabała, 2013).

There is some evidence to support the thesis that roles in workaholics' families are unclear and indeterminate (Robinson after Golińska, 2006) This is likely to be linked to a substantial imbalance in responsibility, uneven division of duties and domination in the family that result from the priority ascribed to work by the addicted person. Gradual overtaking the duties that should be done by the workaholic might lead to the excessive overload among other family members, disturbances in performing the roles of a wife, husband, father or mother and to constant feeling of excess responsibility (co-dependency of spouses, ,parenthood syndrome” experienced by children). The role of the therapy in this area would be to recover a proper profile of the roles performed in family and duties that result from these roles. An essential area of changes should be definition of boundaries between the subsystems. This is important due to the fact that a workaholic usually keeps emotionally away from other family members, which might lead to e.g. unusual intimacy between the spouse and a child. Another area of changes should be disturbed rules that control family life and disturbed communication, both in terms of its form and contents. In a dysfunctional family with addiction problem, communication between individual members of family might occur not directly but with participation of other persons (e.g. a mother being an intermediary between a son and a father). Consistent avoiding talking about problems might also be typical of workaholism. Open expressing of actual emotions is not allowed in these families, leading to the necessity of suppression and developing improper patterns of coping with emotions. Furthermore, other difficulties are often essential for therapies, including reluctance to develop through taking new challenges and implementation of changes, limitation of the contact with the environment and external chaos (Killinger, 2007). The therapies for the spouses and children should emphasize reinforcement of the self-centeredness and meeting your own needs without feeling of guilt. It is typical of dysfunctional families to focus on the addicted person. This is reflected by subordination to their changing expectations and actions aimed at satisfying the needs of the addicted person. Importantly, gradual deprivation of the 
needs of other family members represents a serious threat to the self-esteem and other aspects which are important for the individual development.

Systematic therapy requires participation of the addicted and all their family members.

Due to the readiness for changes and the mechanism of denial, this represents a serious therapeutic obstacle.

Apart from therapeutic measures oriented at the problem, the prevention activities are also very important. Prevention should be focused on the people in the work addiction risk group and their relatives, with particular focus on:

- people from families with improper communicational patterns,

- people from families where the needs for unconditional acceptance are not met,

- people from families with parents experiencing problems of work addiction.

\section{Conclusions}

Workaholism is an addiction that is not connected with embarrassment, but rather with recognition, social approval and prestige associated with high socio-economic status. (Golińska, 2008). External image do not tally with the consequences of developing mechanisms of addiction for the functioning of a workaholic and their family. Mechanisms typical of adaptation of workaholics' partners, described as codependency can with time lead to significant emotional problems and psychosomatic diseases. In the case of children, the consequences may also concern, among other things, repeating in the course of the development of dysfunctional patterns observed in a parent and the effect of a bigger threat is establishing of workaholic behaviours in adult life.

Workaholism is an addiction that requires taking therapeutic action. At the same time, the decision on starting a therapy may be difficult due to the working system of denial, as well as associated with its adaptation functioning of a workaholic's family and strengthening resulting from a positive social assessment of commitment to work. According to the assumption that a family is the system of interrelated parts, both an addict and their family and friends need therapeutic help. Spouses as well as children need influences in the field of psychoeducation and strengthening the skills of change of disadaptation forms of adaptation to arisen difficulties in the family system. Therapeutic measures oriented at workaholic families should take into consideration, among other things, clear definition of the roles performed in the family reinforcing the focus on the needs, relieving from excessive feeling of responsibility, learning open and direct communication and training in terms of coping with difficult emotions (Killinger, 2007).

\section{References}

1. Czabała, J. (2013): Czynniki leczące w psychoterapii, Wydawnictwo Naukowe PWN, Warszawa, $335 \mathrm{p}$.

2. Golińska, L. (2006): Pracoholizm małżonka i rodzica w percepcji i odczuciach współpartnera i dzieci „Nowiny Psychologiczne”2006 (1), pp. 47-55.

3. Golińska, L. (2008): Pracoholizm. Uzależnienie czy pasja, Difin, Warszawa, 184 p. 
4. Golińska L. (2013): Dwie formy pracoholizmu w świetle dualistycznej koncepcji pasji „Przedsiębiorczość i Zarządzanie” 14/5 (1), pp. 117 - 134.

5. Guerreschi, C. (2005): Nowe uzależnienia, Wydawnictwo Salwator, Kraków, 318 p.

6. Killinger, B. (2007): Pracoholicy. Szkoła przetrwania, Dom Wydawniczy Rebis, Poznań, $264 \mathrm{p}$.

7. Kozak, S. (2009): Patologie w środowisku pracy. Zapobieganie i leczenie, Difin, Warszawa, $304 \mathrm{p}$.

8. Malinowska, D. (2014): Pracoholizm. Zjawisko wielowymiarowe, WUJ, Kraków, 164 p.

9. Mieścicka L. (2002): Pracoholizm, Instytut Psychologii Zdrowia, Warszawa, 40 p.

10. Moczydłowska, J. (2005): Rodzinne aspekty uzależnienia od pracy „Małżeństwo i Rodzina", 1/2, pp. 82-85.

11. Sęk, H. (2007): Psychologia kliniczna. T 1,Wydawnictwo Naukowe PWN, Warszawa, $364 \mathrm{p}$.

12. Strzelczyk-Muszyńska, D. (2008): Pracoholik w rodzinie. In: Rodzina i praca $z$ perspektywy wyzwań i zagrożeń (eds.) Golińska, L.; Dudek B., Wydawnictwo Uniwersytetu Łódzkiego, Łódź, 2008, pp. 321-329.

13. Wojdyło, K (2010): Pracoholizm. Perspektywa poznawcza, Difin, Warszawa, 134 p. 